\title{
Propyl gallate inhibits the growth of HeLa cells via caspase- dependent apoptosis as well as a G1 phase arrest of the cell cycle
}

\author{
YONG HWAN HAN, HWA JIN MOON, BO RA YOU, SUNG ZOO KIM, SUHN HEE KIM and WOO HYUN PARK \\ Department of Physiology, Medical School, Centers for Healthcare Technology Development Institute
for Medical Sciences, Chonbuk National University, JeonJu 561-180, Republic of Korea
}

Received November 10, 2009; Accepted December 28, 2009

DOI: $10.3892 /$ or_00000745

\begin{abstract}
Propyl gallate (PG) as a synthetic antioxidant exerts a variety of effects on tissue and cell functions. Here, we evaluated the effects of PG on the growth of HeLa cells in relation to apoptosis and the cell cycle. PG dosedependently inhibited the growth of HeLa cells with an $\mathrm{IC}_{50}$ of approximately $800 \mu \mathrm{M}$ at $24 \mathrm{~h}$. DNA flow cytometric analysis indicated that PG significantly induced a G1 phase arrest of the cell cycle along with an increase in the cyclindependent kinase inhibitor (CDKI) p27. In addition, PG induced apoptosis, which was accompanied by the loss of mitochondrial membrane potential (MMP; $\Delta \Psi_{\mathrm{m}}$ ), activation of caspase- 3 and caspase- 8 and PARP cleavage. All the tested caspase inhibitors (pan-caspase, caspase- $3,-8$ or -9 inhibitor) significantly rescued HeLa cells from PG-induced cell death. However, none of the caspase inhibitors prevented the loss of MMP $\left(\Delta \Psi_{\mathrm{m}}\right)$ induced by PG. In conclusion, PG inhibited the growth of HeLa cells via caspase-dependent apoptosis as well as a G1 phase arrest of the cell cycle.
\end{abstract}

\section{Introduction}

Propyl gallate (PG, 3,4,5-trihydroxybenzoic acid propyl ester) is used as a synthetic antioxidant in processed food, cosmetics and food packing materials, to prevent rancidity and spoilage. PG is also used to preserve and stabilize medicinal

Correspondence to: Dr Woo Hyun Park, Department of Physiology, Medical School, Chonbuk National University, JeonJu 561-180, Republic of Korea

E-mail: parkwh71@chonbuk.ac.kr

Abbreviations: PG, propyl gallate; ROS, reactive oxygen species; PARP, poly(ADP-ribose) polymerase; $\mathrm{MMP}\left(\Delta \Psi_{\mathrm{m}}\right)$, mitochondrial membrane potential; FBS, fetal bovine serum; MTT, 3-(4,5dimethylthiazol-2-yl)-2,5-diphenyltetrazolium bromide; PI, propidium iodide; FITC, fluorescein isothiocyanate; Z-VAD-FMK, benzyloxycarbonyl-Val-Ala-Asp-fluoromethylketon; Z-DEVDFMK, benzyloxycarbonyl-Asp-Glu-Val-Asp-fluoromethylketon; Z-IETD-FMK, benzyloxycarbonyl-Ile-Glu-Thr-Asp-fluoromethylketon; Z-LEHD-FMK, benzyloxycarbonyl-Leu-Glu-His-Asp-fluoromethylketon

Key words: propyl gallate, apoptosis, HeLa, caspase, cell cycle preparations on the US Food and Drug Administration list (1). Because of its prevalent usage, the potential toxicity of PG has been investigated in vivo $(2,3)$ and in vitro, to assess various toxicological properties, i.e., mutagenicity (4) and cytogenetic effects (5). Despite the assumed low toxicity of PG, it exerts a variety of effects on tissue and cell functions. Several studies demonstrate the benefits of PG as an antioxidant $(6,7)$ and a chemopreventive agent $(8)$. For instances, PG is an efficient protector of liver cells from lipid peroxidation by oxygen radicals (3). PG also has protective effects against oxidative DNA damage using 8-oxoguanine formation as a marker (7). In contrast, it is reported that PG exerted prooxidant properties (9-11). PG is cytotoxic to isolated rat hepatocytes because it impairs mitochondria, leading to ATP depletion (12). PG inhibits growth of microorganisms by inhibiting respiration and nucleic acid synthesis (13). Controversially, the effects of PG can be enhancing or suppressing on carcinogenesis and mutagenesis $(4,14)$. Antioxidative and cytoprotective properties of PG may change to prooxidative, cytotoxic and genotoxic properties in the presence of $\mathrm{Cu}$ (II) (15). Therefore, in order to clarify the discrepancy between the different effects of PG, further studies need to be performed to re-evaluate its function and safety on cells and tissues.

The mechanism of apoptosis involves mainly two signaling pathways, the mitochondrial pathway and the cell death receptor pathway (16-18). The key element in the mitochondrial pathway is the efflux of cytochrome $c$ from mitochondria to cytosol, where it subsequently forms a complex (apoptosome) with Apaf-1 and caspase-9, leading to the activation of the caspase-3 (19). The cell death receptor pathway is characterized by binding cell death ligands and cell death receptors, and subsequently activates caspase- 8 and caspase-3 (20,21). Caspase- 3 is an executioner caspase, which activation can systematically dismantle cells by cleaving key proteins such as PARP.

Since little is known about the relationship between PG and cancer cells, in this study we evaluated the effects of PG on the growth of human cervix adenocarcinoma HeLa cells and investigated its anti-growth mechanism in relation to apoptosis as well as cell cycle arrest.

\section{Materials and methods}

Cell culture. The human cervix adenocarcinoma HeLa cells were obtained from the ATCC and maintained in a humidified incubator containing $5 \% \mathrm{CO}_{2}$ at $37^{\circ} \mathrm{C}$. HeLa cells were 
cultured in RPMI-1640 supplemented with $10 \%$ fetal bovine serum (FBS) and 1\% penicillin-streptomycin (Gibco BRL, Grand Island, NY). Cells were routinely grown in 100-mm plastic tissue culture dishes (Nunc, Roskilde, Denmark) and harvested with a solution of trypsin-EDTA while in a logarithmic phase of growth. Cells were maintained in these culture conditions for all experiments.

Reagents. PG was purchased from the Sigma-Aldrich Chemical Co. (St. Louis, MO). PG was dissolved in ethanol at $200 \mathrm{mM}$ as a stock solution. The pan-caspase inhibitor (Z-VAD-FMK; benzyloxycarbonyl-Val-Ala-Asp-fluoromethylketone, caspase-3 inhibitor (Z-DEVD-FMK; benzyloxycarbonyl-Asp-Glu-Val-Asp-fluoromethylketone, caspase-8 inhibitor (Z-IETD-FMK; benzyloxycarbonyl-Ile-Glu-Thr-Aspfluoromethylketone and caspase-9 inhibitor (Z-LEHD-FMK; benzyloxycarbonyl-Leu-Glu-His-Asp-fluoromethylketone were obtained from R\&D Systems, Inc. (Minneapolis, MN) and dissolved in DMSO (Sigma) at $10 \mathrm{mM}$ as a stock solution. Cells were pretreated with caspase inhibitor for $30 \mathrm{~min}$ prior to treatment with PG. Ethanol (0.2\%) and DMSO (0.2\%) were used as a control vehicle. All stock solutions were wrapped in foil and kept at $-20^{\circ} \mathrm{C}$.

Cell growth assay. The effect of PG on HeLa cell growth was determined by trypan blue exclusion cell counting or measuring 3-(4,5-dimethylthiazol-2-yl)-2,5-diphenyltetrazolium bromide (MTT) dye absorbance of living cells as previously described (22). In brief, cells $\left(3 \times 10^{5}\right.$ cells per well) were seeded in 24-well plates (Nunc) for cell counting, and cells $\left(5 \times 10^{4}\right.$ cells per well) were seeded in 96 -well microtiter plates for an MTT assay. After exposure to the doses of 100-1600 $\mu \mathrm{M}$ PG for $24 \mathrm{~h}$, cells in 24- or 96-well plates were collected with trypsin digestion for trypan blue exclusion cell counting or for an MTT assay. Twenty microliters of MTT (Sigma) solution ( $2 \mathrm{mg} / \mathrm{ml}$ in PBS) were added to each well of 96 -well plates. The plates were incubated for 4 additional hours at $37^{\circ} \mathrm{C}$. MTT solution in the medium was aspirated off and $200 \mu 1$ of DMSO were added to each well to solubilize the formazan crystals formed in viable cells. Optical density was measured at $570 \mathrm{~nm}$ using a microplate reader (Spectra MAX 340, Molecular Devices Co., Sunnyvale, CA). Each plate contained multiple wells at a given experimental condition and multiple control wells. This procedure was replicated for 2-4 plates per condition.

Cell cycle analysis. Cell cycle distributions in cells were determined by propidium iodide (PI, Sigma-Aldrich; Ex/Em = $488 \mathrm{~nm} / 617 \mathrm{~nm}$ ) staining as previously described (23). In brief, $1 \times 10^{6}$ cells were incubated with the designated doses of PG with or without caspase inhibitor for $24 \mathrm{~h}$. Cells were then washed with PBS and fixed in 70\% ethanol. Cells were washed again with PBS, then incubated with PI $(10 \mu \mathrm{g} / \mathrm{ml})$ with simultaneous RNase treatment at $37^{\circ} \mathrm{C}$ for $30 \mathrm{~min}$. Cell DNA content was measured using a FACStar flow cytometer (Becton-Dickinson, San Jose, CA) and analyzed using lysis II and CellFit software (Becton-Dickinson) or ModFit software (Verity Software House, Inc., ME).

Annexin $V$ staining. Apoptosis was determined by staining cells with annexin V-fluorescein isothiocyanate (FITC)
$(\mathrm{Ex} / \mathrm{Em}=488 \mathrm{~nm} / 519 \mathrm{~nm})$ as previously described (24). In brief, $1 \times 10^{6}$ cells were incubated with the designated doses of PG with or without caspase inhibitors for $24 \mathrm{~h}$. Cells were washed twice with cold PBS and then resuspended in $500 \mu 1$ of binding buffer (10 mM HEPES/NaOH pH 7.4, $140 \mathrm{mM}$ $\mathrm{NaCl}, 2.5 \mathrm{mM} \mathrm{CaCl}$ ) at a concentration of $1 \times 10^{6}$ cells $/ \mathrm{ml}$. Five microliters of annexin V-FITC (PharMingen, San Diego, CA) was then added to these cells, which were analyzed with a FACStar flow cytometer (Becton-Dickinson).

Measurement of MMP $\left(\Delta \Psi_{m}\right)$. The $\operatorname{MMP}\left(\Delta \Psi_{\mathrm{m}}\right)$ was measured using the Rhodamine 123 fluorescent dye $(E x / E m=485 \mathrm{~nm} /$ $535 \mathrm{~nm}$ ), which preferentially enters mitochondria, as previously described (25). In brief, $1 \times 10^{6}$ cells were incubated with the designated doses of PG with or without caspase inhibitors for $24 \mathrm{~h}$. Cells were washed twice with PBS and incubated with Rhodamine $123\left(0.1 \mu \mathrm{g} / \mathrm{ml}\right.$; Sigma) at $37^{\circ} \mathrm{C}$ for $30 \mathrm{~min}$. Rhodamine 123 staining intensity was determined by flow cytometry. Rhodamine 123 negative cells indicate the loss of MMP $\left(\Delta \Psi_{\mathrm{m}}\right)$ in HeLa cells. MMP $\left(\Delta \Psi_{\mathrm{m}}\right)$ levels in cells except MMP $\left(\Delta \Psi_{\mathrm{m}}\right)$ loss cells were expressed as mean fluorescence intensity (MFI), which was calculated by CellQuest software.

Western blot analysis. The expression of apoptosis-related proteins was evaluated by Western blot analysis as previously described (26). In brief, $1 \times 10^{6}$ cells were incubated with the designated doses of PG for $24 \mathrm{~h}$. The cells were then washed in PBS and suspended in lysis buffer [20 mM HEPES pH 7.9, $20 \%$ glycerol, $200 \mathrm{mM} \mathrm{KCl,} 0.5 \mathrm{mM}$ EDTA, 0.5\% NP40, $0.5 \mathrm{mM}$ DTT, $1 \%$ protease inhibitor cocktail (Sigma)]. Lysates were then collected and stored at $-20^{\circ} \mathrm{C}$ until further use. Supernatant protein concentration was determined by the Bradford method. Supernatant samples containing $40 \mu \mathrm{g}$ total protein were resolved by 8 or $15 \%$ SDS-PAGE gel depending on the target protein sizes, transferred to Immobilon-P PVDF membranes (Millipore, Billerica, MA) by electroblotting, and probed with anti-Bcl-2, anti-caspase-3, anti-PARP, anti-p27 and anti- $\beta$-actin antibodies (Santa Cruz Biotechnology, Santa Cruz, CA). Membranes were incubated with horseradish peroxidase-conjugated secondary antibodies. Blots were developed using an ECL kit (Amersham, Arlington Heights, IL).

Quantification of caspase-3 and caspase- 8 activity. The activity of caspase- 3 and caspase- 8 was assessed using caspase- 3 and caspase- 8 Colorimetric Assay kits (R\&D Systems, Inc.), as previously described (27). In brief, $1 \times 10^{6}$ cells were incubated with or without PG for $24 \mathrm{~h}$, then washed in PBS and suspended in 5 volumes of lysis buffer [20 mM HEPES pH 7.9, 20\% glycerol, $200 \mathrm{mM} \mathrm{KCl,} 0.5 \mathrm{mM}$ EDTA, $0.5 \%$ NP40, $0.5 \mathrm{mM}$ DTT, $1 \%$ protease inhibitor cocktail (Sigma)]. Lysates were then collected and stored at $-20^{\circ} \mathrm{C}$ until used. Protein concentration was determined by the Bradford method. Supernatant samples containing $100 \mu \mathrm{g}$ total protein were added to DEVD-pNA or IETD-pNA in 96-well microtiter plates (Nunc) and incubated at $37^{\circ} \mathrm{C}$ for $1 \mathrm{~h}$. Optical density was measured at $405 \mathrm{~nm}$ using a microplate reader (Spectra MAX 340, Molecular Devices Co.). Each plate contained multiple wells of a given experimental condition and multiple 
A

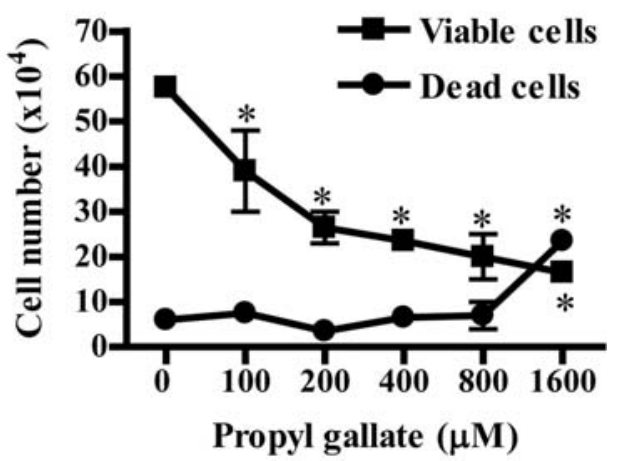

B

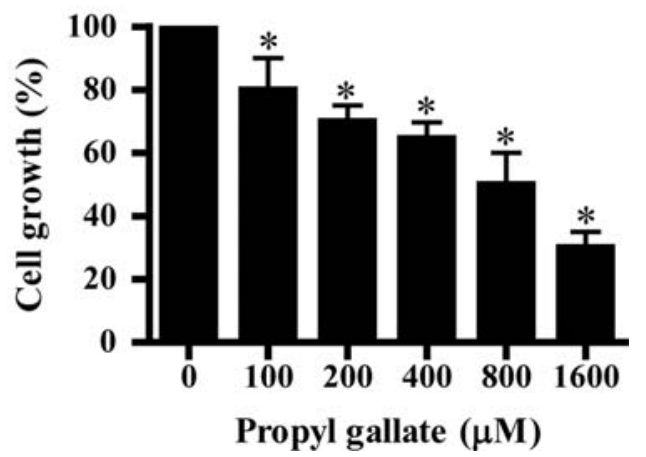

Figure 1. Effects of PG on the growth of HeLa cells in vitro. Exponentiallygrowing cells were treated with the indicated concentrations of PG for $24 \mathrm{~h}$ Cell number (A) and cell growth (B) were assessed by trypan blue exclusion cell counting and an MTT assay, respectively. ${ }^{*} \mathrm{P}<0.05$ compared with the PG-untreated control cell group.

control wells. Caspase activity is expressed in arbitrary absorbance units (absorbance at a wavelength of $405 \mathrm{~nm}$ ).

Statistical analysis. The results shown in Figures represent the mean of at least three independent experiments; bar, SD. The data were analyzed using Instat software (GraphPad Prism4, San Diego, CA). The Student's t-test or one-way analysis of variance (ANOVA) with post hoc analysis using Tukey's multiple comparison test for parametric data. The statistical significance was defined as $\mathrm{P}<0.05$.

\section{Results}

Effects of PG on the growth of HeLa cells. We examined the effect of PG on the growth of HeLa cell by trypan blue cell counting. Treatment with 100-1600 $\mu \mathrm{M}$ PG significantly decreased the population of live HeLa cells for $24 \mathrm{~h}$ in a dose-dependent manner (Fig. 1A). In contrast, the number of dead cells increased only at the concentration of $1600 \mu \mathrm{M}$ PG (Fig. 1A). Collectively, the ratio of dead cells to viable cells was increased. When the growth of HeLa cells after treatment with PG was also investigated by an MTT assay, dose-dependent reduction of cell growth was observed in HeLa cells with an $\mathrm{IC}_{50}$ of $\sim 800 \mu \mathrm{M}$ following treatment with PG for $24 \mathrm{~h}$ (Fig. 1B). In addition, $100 \mu \mathrm{M}$ PG reduced the growth of HeLa cells about $>80 \%$ at $72 \mathrm{~h}$ (data not shown). Thus, an $\mathrm{IC}_{50}$ of PG in HeLa cells at $72 \mathrm{~h}$ was $<50 \mu \mathrm{M}$.

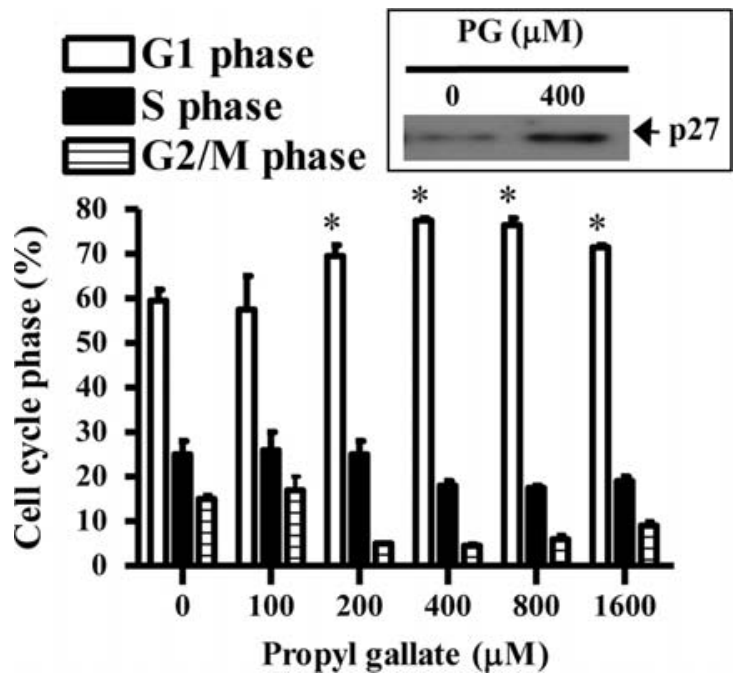

Figure 2. Effects of PG on the cell cycle distribution in HeLa cells Exponentially-growing cells were treated with the indicated concentrations of PG for $24 \mathrm{~h}$. The changes of cell cycle phase distribution were assessed by DNA flow cytometric analysis. The inside figure indicates the expression of p27 protein in PG-treated and -untreated HeLa cells via Western blot. ${ }^{*} \mathrm{P}<0.05$ compared with the $\mathrm{PG}$-untreated control cell group.

Because the incubation time of $72 \mathrm{~h}$ was too long to observe the direct effect of PG on HeLa cells, cells were treated with $\mathrm{PG}$ for $24 \mathrm{~h}$ in the whole study.

Effects of PG on the cell cycle distribution in HeLa cells. We examined the effect of PG on the cell cycle distribution in live HeLa cells without sub-G1 DNA content cells. As shown in Fig. 2, DNA flow cytometric analysis indicated that treatment with 200-1600 $\mu$ M PG significantly induced a G1 phase arrest of the cell cycle at $24 \mathrm{~h}$. In addition, a cyclin-dependent kinase inhibitor (CDKI), p27 which typically causes cells to arrest in the G1 phase of the cell cycle was increased in PG-treated HeLa cells. It is plausible that a G1 phase arrest in PG-treated HeLa cells was regulated by cell cycle regulated proteins such as $\mathrm{p} 27$.

Effects of $P G$ on apoptosis and MMP $\left(\Delta \Psi_{m}\right)$ in HeLa cells. Next, we determined whether PG induces apoptosis in HeLa cells using annexin $\mathrm{V}$ staining. As shown in Fig. 3A, the proportion of annexin V-staining cells in PG-treated cells was increased in a dose-dependent manner, which indicates that PG-induced HeLa cell death occurred via apoptosis. To elucidate the effect of PG on MMP $\left(\Delta \Psi_{\mathrm{m}}\right)$ using Rhodamine 123 , cells were treated with the indicated doses of PG for $24 \mathrm{~h}$ (Fig. 3B). Treatment with PG induced the loss of MMP $\left(\Delta \Psi_{\mathrm{m}}\right)$ in HeLa cells in a dose-dependent manner. Following exposure to $800 \mu \mathrm{M}$ PG for $24 \mathrm{~h}$, the percent of Rhodamine 123 negative staining [MMP $\left(\Delta \Psi_{\mathrm{m}}\right)$ loss] cells was increased $\sim 25 \%$ compared with that of control cells. In relation to the levels of MMP $\left(\Delta \Psi_{\mathrm{m}}\right)$ in live HeLa cells, treatment with $400 \mu \mathrm{M}$ PG reduced the MMP ( $\left.\Delta \Psi_{\mathrm{m}}\right)$ about $25 \%$ (Fig. 3C). The dramatic decrease in MMP $\left(\Delta \Psi_{\mathrm{m}}\right)$ levels was observed in above $800 \mu \mathrm{M}$ PG-treated cells (Fig. 3C).

Examination of $\mathrm{Bcl}-2$ regulation during $\mathrm{PG}$-induced apoptosis revealed that $\mathrm{Bcl}-2$ protein level was decreased 
A

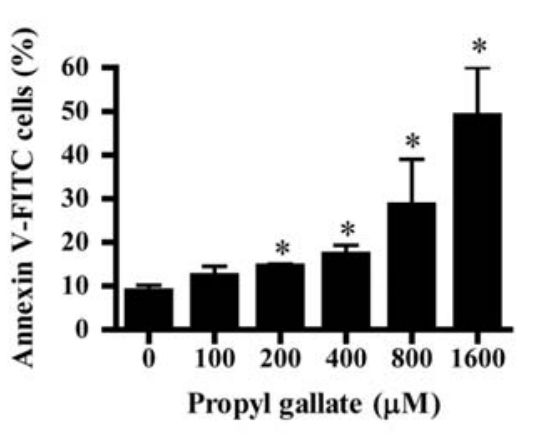

D

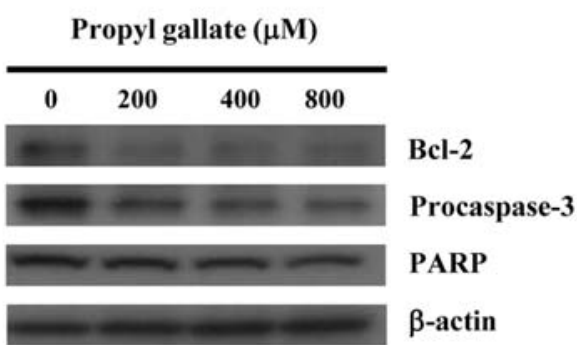

B

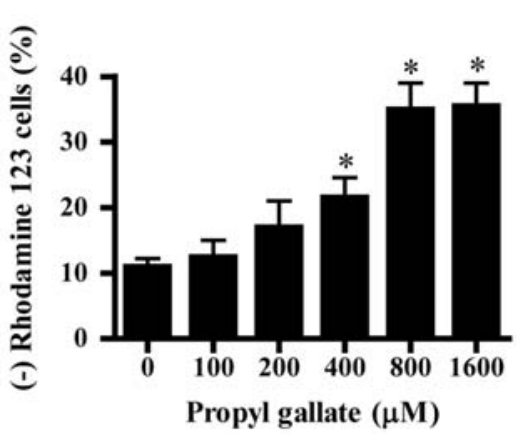

$\mathbf{E}$

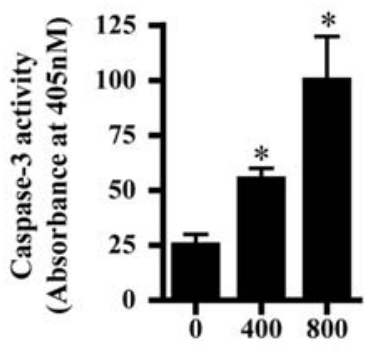

Propyl gallate $(\mu \mathbf{M})$
C

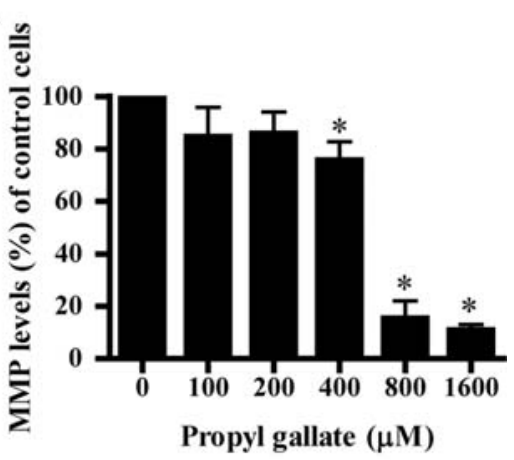

F

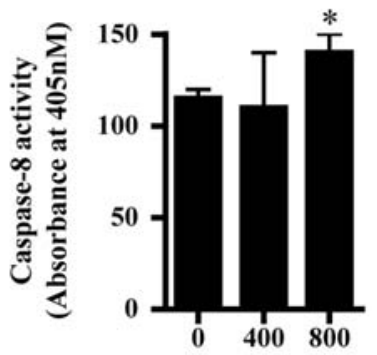

Propyl gallate $(\mu \mathrm{M})$

Figure 3. Effects of PG on apoptosis and apoptosis-related proteins in HeLa cells. Exponentially-growing cells were treated with the indicated concentrations of PG for $24 \mathrm{~h}$. (A) The graph shows the percent of annexin V positive cells. (B) The graph shows the percent of Rhodamine 123 negative [MMP ( $\Delta \Psi_{\mathrm{m}}$ ) loss] cells. (C) The graph shows the percent of MMP $\left(\Delta \Psi_{\mathrm{m}}\right)$ levels in HeLa cells. (D) Samples $(40 \mu \mathrm{g})$ of protein extracts were resolved by SDS-PAGE gel, transferred onto the PVDF membranes, and immunoblotted with the indicated antibodies against Bcl-2, caspase-3, PARP and B-actin. (E) and (F) Graphs show caspase- 3 and caspase- 8 activities in PG-treated and -untreated HeLa cells, respectively. ${ }^{*} \mathrm{P}<0.05$ compared with the PG-untreated control group.

in PG-treated HeLa cells (Fig. 3D). Unfortunately, we could not detect the pro-apoptotic protein, Bax in HeLa cells with our anti-Bax antibody. Caspase-3 plays an essential role as an executioner in apoptosis (28). Therefore, we examined whether PG activate caspase-3 during the induction of apoptosis. The level of pro-caspase-3 (32 kDa precursor) was significantly reduced in PG-treated cells as compared with the level of the control cells (Fig. 3D), which suggests that the activation of caspase-3 occurred in PG-treated cells. In fact, PG treatment increased caspase-3 activity in HeLa cells (Fig. 3E). Caspase-8, which is related to the cell death receptor pathway $(17,18)$, was also activated by treatment with PG (Fig. 3F). Cleavage of PARP-1 provides one of the most recognizable examples in apoptosis (29). Western blotting showed that the intact $116 \mathrm{kDa}$ moiety of PARP was decreased in PG-treated HeLa cells, implying that PARP was degraded in PG-treated cells (Fig. 3D).

Effects of caspase inhibitors on apoptosis and $M M P\left(\Delta \Psi_{m}\right)$ in $P G$-treated HeLa cells. To determine which caspases are required for PG-induced apoptosis, cells were treated with caspase inhibitors at a concentration of $15 \mu \mathrm{M}$. Treatment with $\mathrm{Z}-\mathrm{VAD}$ resulted in the marked rescue of HeLa cells from PG-induced apoptosis at $24 \mathrm{~h}$, as measured by the population of sub-G1 cells (Fig. 4A) and annexin V staining (Fig. 4B). Inhibitors for caspase- 3 , caspase- 8 and caspase- 9 also significantly prevented apoptotic events in PG-treated HeLa cells (Fig. 4A and B). Interestingly, caspase inhibitors did not prevent the loss of MMP ( $\left.\Delta \Psi_{\mathrm{m}}\right)$ induced by PG (Fig. 4C). Instead, pan-caspase inhibitor and caspase-9 inhibitor mildly intensified the loss. In relation to the levels of MMP $\left(\Delta \Psi_{\mathrm{m}}\right)$, all of the tested caspase inhibitors did not recover the reduced MMP $\left(\Delta \Psi_{\mathrm{m}}\right)$ levels in PG-treated HeLa cells (Fig. 4D). Caspase-9 inhibitor decreased the MMP $\left(\Delta \Psi_{\mathrm{m}}\right)$ level in PGtreated or -untreated HeLa cells (Fig. 4D).

\section{Discussion}

In the present study, we focused on assessing the effects of PG on the growth of HeLa cells in relation to the cell cycle arrest and apoptosis. Treatment with PG significantly decreased the population of HeLa cells for $24 \mathrm{~h}$ in a dosedependent manner. The ratio of dead cells to live cells was increased after treatment with PG compared with PG-untreated cells. In addition, PG induced apoptosis in HeLa cells in a dose-dependent manner as evidenced by sub-G1 cells and annexin V staining cells. To explain the mechanism of cell growth inhibition by PG concerning cell cycle changes, we did cell cycle analysis in PG-treated cells. DNA flow cytometric analysis indicated that treatment with PG significantly induced a G1 phase arrest of the cell cycle for $24 \mathrm{~h}$. Because treatment with $400 \mu \mathrm{M}$ PG strongly inhibited the growth of HeLa cells by approximately $40 \%$, but slightly induced cell death by approximately $15 \%$ in view of sub-G1 cells and annexin $\mathrm{V}$ staining cells, the G1 phase arrest by PG can be considered as a pathway to suppress the growth of HeLa cells. 
A

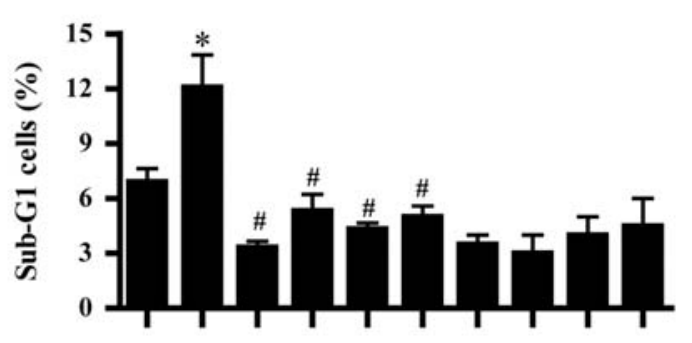

C

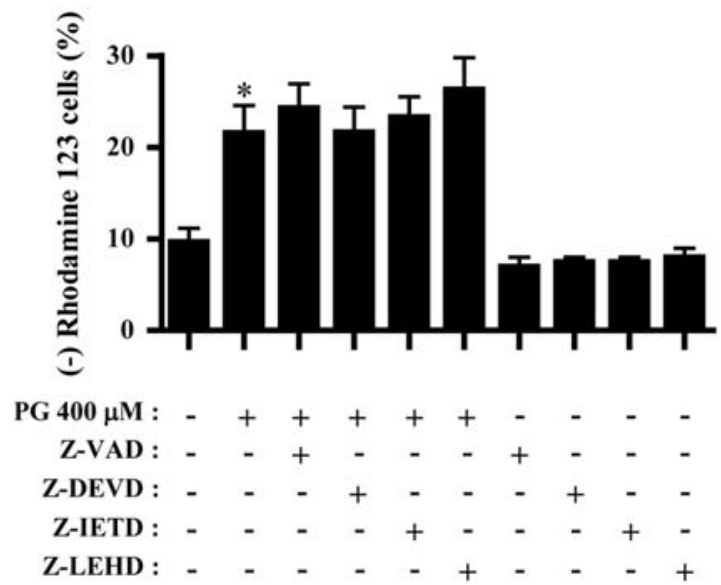

B

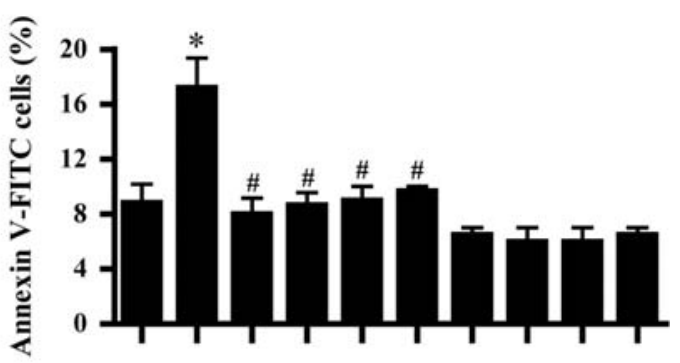

D

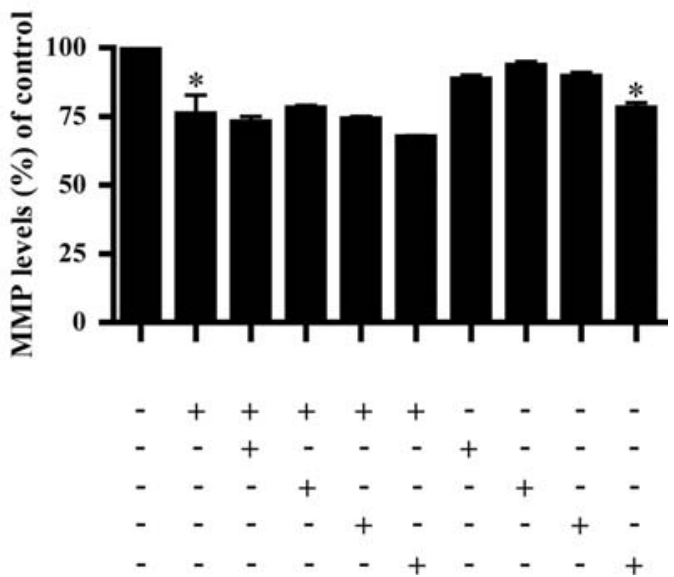

Figure 4. Effects of caspase inhibitors on apoptosis and MMP $\left(\Delta \Psi_{\mathrm{m}}\right)$ in PG-treated HeLa cells. Exponentially-growing cells were treated with $400 \mu \mathrm{M}$ PG and/or each caspase inhibitor (15 $\mu \mathrm{M})$ for $24 \mathrm{~h}$. (A) and (B) Graphs show the percent of sub-G1 cells (A) and annexin V staining cells (B), as measured with a FACStar flow cytometer. (C) and (D) The graphs show the percent of Rhodamine 123 negative [MMP ( $\left.\Delta \Psi_{\mathrm{m}}\right)$ loss] cells $(\mathrm{C})$ and MMP ( $\left.\Delta \Psi_{\mathrm{m}}\right)$ levels $(\mathrm{D})$ in HeLa cells, as measured with a FACStar flow cytometer. ${ }^{*} \mathrm{P}<0.05$ compared with the control group. ${ }^{\#} \mathrm{P}<0.05$ compared with cells treated with $\mathrm{PG}$ only.

Collectively, PG inhibited the growth of HeLa cells via apoptosis as well as a G1 phase arrest of the cell cycle.

To gain insight into the molecular mechanism involved in apoptosis by PG, the expression of apoptosis-related proteins and changes in MMP $\left(\Delta \Psi_{\mathrm{m}}\right)$ were assessed in HeLa cells. Many apoptotic agents increase Bax and/or decrease Bcl-2 protein expression in target cells during the apoptotic process. Likewise, PG-induced apoptosis in HeLa cells was accompanied by the down-regulation of Bcl-2. It has been suggested that a high ratio of Bax to $\mathrm{Bcl}-2$ can cause the collapse of MMP $\left(\Delta \Psi_{\mathrm{m}}\right)$, resulting in cytochrome $c$ release and apoptosis (30). In the cytosol, cytochrome $c$ forms an apoptosome that is composed of Apaf-1 and pro-caspase-9, resulting in the activation of caspase-9. Caspase- 9 activates the effector procaspases, including pro-caspase-3, to carry out the process of apoptosis (31). Correspondingly, PG treatment reduced the levels of MMP $\left(\Delta \Psi_{\mathrm{m}}\right)$, induced the loss of MMP $\left(\Delta \Psi_{\mathrm{m}}\right)$, and activated caspase-3 in HeLa cells. We also observed that the proportion of annexin $\mathrm{V}$ positive staining cells was similar to that of Rhodamine 123 negative staining cells. This result suggests that apoptosis is accompanied by the alteration of mitochondria function. In fact, it is reported that PG is cytotoxic to isolated rat hepatocytes because it impairs mitochondria, leading to ATP depletion (12).

To determine which caspases are required for the induction of apoptosis, PG-treated HeLa cells were incubated with various caspase inhibitors. Treatment with caspase inhibitors tested in this experiment significantly rescued HeLa cells from PG-induced apoptosis at $24 \mathrm{~h}$. Z-VAD (pan-caspase inhibitor) treatment had a stronger effect on reducing apoptosis than any other inhibitors. These data suggest that activation of caspase-3, -8 and -9 is necessary for the induction of apoptosis and also suggest that other executioners such as caspase- 6 and -7 are also required for the complete induction of apoptosis by PG. In particular, caspase- 8 activation in PG-induced apoptosis was observed in HeLa cells. The exact mechanism involved needs further study, since caspase- 8 activation is associated with the cell death receptor pathway of apoptosis $(17,18)$.

With regard to the MMP $\left(\Delta \Psi_{\mathrm{m}}\right)$, caspase inhibitors did not prevent the loss of MMP $\left(\Delta \Psi_{\mathrm{m}}\right)$ induced by PG. Caspase inhibitors also did not recover the decreased $\operatorname{MMP}\left(\Delta \Psi_{\mathrm{m}}\right)$ level in PG-treated HeLa cells. Instead, some of the caspase inhibitors (pan-caspase inhibitor and caspase-9 inhibitor) intensified the MMP $\left(\Delta \Psi_{\mathrm{m}}\right)$ loss and the reduced levels. These results implied that the loss of MMP $\left(\Delta \Psi_{\mathrm{m}}\right)$ following treatment with PG activated caspases and consequently induced apoptosis, and also the activation of caspase by PG did not positively intensify the MMP $\left(\Delta \Psi_{\mathrm{m}}\right)$ loss. Furthermore, the loss of MMP $\left(\Delta \Psi_{\mathrm{m}}\right)$ by PG might be not enough to fully trigger apoptosis in HeLa cells under the inhibition of caspase activity. In addition, none of the caspase inhibitors significantly altered the cell cycle distribution in PG-treated HeLa cells (data not shown). This result suggests that the activation 
of caspases during PG-induced apoptosis in HeLa cells is not tightly involved in cell cycle regulation.

In conclusion, PG treatment inhibited the growth of HeLa cells via caspase-dependent apoptosis as well as cell cycle arrest. Since little is known about the relationship between PG and cancer cells, our results provide the first information on the molecular anti-growth mechanisms of PG in cancer cells.

\section{Acknowledgements}

This research was supported by a grant of the Korea Healthcare Technology R\&D Project, Ministry for Health, Welfare and Family Affairs and Republic of Korea (A084194) and the Korea Research Foundation Grant funded by the Government of the Republic of Korea (MOEHRD).

\section{References}

1. Daniel JW: Metabolic aspects of antioxidants and preservatives. Xenobiotica 16: 1073-1078, 1986.

2. Dacre JC: Long-term toxicity study of n-propyl gallate in mice. Food Cosmet Toxicol 12: 125-129, 1974.

3. Wu TW, Fung KP, Zeng LH, Wu J and Nakamura H: Propyl gallate as a hepatoprotector in vitro and in vivo. Biochem Pharmacol 48: 419-422, 1994.

4. Rosin MP and Stich HF: Enhancing and inhibiting effects of propyl gallate on carcinogen-induced mutagenesis. J Environ Pathol Toxicol 4: 159-167, 1980.

5. Abdo KM, Huff JE, Haseman JK and Alden CJ: No evidence of carcinogenicity of D-mannitol and propyl gallate in F344 rats or B6C3F1 mice. Food Chem Toxicol 24: 1091-1097, 1986.

6. Reddan JR, Giblin FJ, Sevilla M, Padgaonkar V, Dziedzic DC, Leverenz VR, Misra IC, Chang JS and Pena JT: Propyl gallate is a superoxide dismutase mimic and protects cultured lens epithelial cells from $\mathrm{H}_{2} \mathrm{O}_{2}$ insult. Exp Eye Res 76: 49-59, 2003.

7. Chen $\mathrm{CH}$, Liu TZ, Chen $\mathrm{CH}$, Wong $\mathrm{CH}$, Chen $\mathrm{CH}$, Lu FJ and Chen SC: The efficacy of protective effects of tannic acid, gallic acid, ellagic acid, and propyl gallate against hydrogen peroxideinduced oxidative stress and DNA damages in IMR-90 cells Mol Nutr Food Res 51: 962-968, 2007.

8. Hirose M, Yada H, Hakoi K, Takahashi S and Ito N: Modification of carcinogenesis by alpha-tocopherol, t-butylhydroquinone, propyl gallate and butylated hydroxytoluene in a rat multiorgan carcinogenesis model. Carcinogenesis 14: 2359-2364, 1993.

9. Kobayashi H, Oikawa S, Hirakawa K and Kawanishi S: Metalmediated oxidative damage to cellular and isolated DNA by gallic acid, a metabolite of antioxidant propyl gallate. Mutat Res 558: 111-120, 2004.

10. Kawanishi S, Oikawa S and Murata M: Evaluation for safety of antioxidant chemopreventive agents. Antioxid Redox Signal 7: 1728-1739, 2005.

11. Han YH and Park WH: Propyl gallate inhibits the growth of HeLa cells via regulating intracellular GSH level. Food and chemical toxicology. Br Indust Biol Res Assoc 47: 2531-2538, 2009.

12. Nakagawa Y, Nakajima K, Tayama S and Moldeus P: Metabolism and cytotoxicity of propyl gallate in isolated rat hepatocytes: effects of a thiol reductant and an esterase inhibitor. Mol Pharmacol 47: 1021-1027, 1995.
13. Boyd I and Beveridge EG: Relationship between the antibacterial activity towards Escherichia coli NCTC 5933 and the physicochemical properties of some esters of 3,4,5-trihydroxybenzoic acid (Gallic acid). Microbios 24: 173-184, 1979.

14. Miller C, Castonguay A and Teel RW: Modulation of the mutagenicity and metabolism of the tobacco-specific nitrosamine 4-(methylnitrosamino)-1-(3-pyridyl)-1-butanone (NNK) by phenolic compounds. Mutat Res 368: 221-233, 1996.

15. Jacobi H, Eicke B and Witte I: DNA strand break induction and enhanced cytotoxicity of propyl gallate in the presence of copper(II). Free Radic Biol Med 24: 972-978, 1998.

16. Shi Y: Mechanisms of caspase activation and inhibition during apoptosis. Mol Cell 9: 459-470, 2002.

17. Ashkenazi A and Dixit VM: Death receptors: signaling and modulation. Science 281: 1305-1308, 1998.

18. Budihardjo I, Oliver H, Lutter M, Luo X and Wang X: Biochemical pathways of caspase activation during apoptosis. Ann Rev Cell Dev Biol 15: 269-290, 1999.

19. Mehmet H: Caspases find a new place to hide. Nature 403: 29-30, 2000.

20. Hengartner MO: The biochemistry of apoptosis. Nature 407: 770-776, 2000.

21. Liu X, Yue P, Zhou Z, Khuri FR and Sun SY: Death receptor regulation and celecoxib-induced apoptosis in human lung cancer cells. J Nat Cancer Inst 96: 1769-1780, 2004.

22. Park WH, Seol JG, Kim ES, Hyun JM, Jung CW, Lee CC, Kim BK and Lee YY: Arsenic trioxide-mediated growth inhibition in MC/CAR myeloma cells via cell cycle arrest in association with induction of cyclin-dependent kinase inhibitor, p21, and apoptosis. Cancer Res 60: 3065-3071, 2000.

23. Han YH, Kim SZ, Kim SH and Park WH: Arsenic trioxide inhibits the growth of Calu- 6 cells via inducing a G2 arrest of the cell cycle and apoptosis accompanied with the depletion of GSH. Cancer Lett 270: 40-55, 2009.

24. Han YH, Kim SZ, Kim SH and Park WH: Apoptosis in pyrogallol-treated Calu- 6 cells is correlated with the changes of intracellular GSH levels rather than ROS levels. Lung Cancer 59: 301-314, 2008.

25. Han YH, Kim SZ, Kim SH and Park WH: Arsenic trioxide inhibits growth of As4.1 juxtaglomerular cells via cell cycle arrest and caspase-independent apoptosis. Am J Physiol Renal Physiol 293: F511-F520, 2007.

26. Han YH, Kim SW, Kim SH, Kim SZ and Park WH: 2,4Dinitrophenol induces G1 phase arrest and apoptosis in human pulmonary adenocarcinoma Calu-6 cells. Toxicol In Vitro 22: 659-670, 2008.

27. Kim SW, Han YW, Lee ST, Jeong HJ, Kim SH, Kim IH, Lee SO, Kim DG, Kim SZ and Park WH: A superoxide anion generator, pyrogallol, inhibits the growth of HeLa cells via cell cycle arrest and apoptosis. Mol Carcinog 47: 114-125, 2008.

28. Porter AG and Janicke RU: Emerging roles of caspase- 3 in apoptosis. Cell Death Differ 6: 99-104, 1999.

29. Lazebnik YA, Kaufmann SH, Desnoyers S, Poirier GG and Earnshaw WC: Cleavage of poly(ADP-ribose) polymerase by a proteinase with properties like ICE. Nature 371: 346-347, 1994.

30. Yang J, Liu X, Bhalla K, Kim CN, Ibrado AM, Cai J, Peng TI, Jones DP and Wang X: Prevention of apoptosis by $\mathrm{Bcl}-2$ : release of cytochrome $\mathrm{c}$ from mitochondria blocked. Science 275: 1129-1132, 1997.

31. Cohen GM: Caspases: the executioners of apoptosis. Biochem J 326 (Pt 1): 1-16, 1997. 